\title{
Neogothic Orthodox Churches and Chapels Built Near St. Petersburg and in the Russian Province (the Second Half of XVIII - the Early XIX Centuries)
}

\author{
Igor Yamshanov ${ }^{1, \text { a }}$ \\ ${ }^{1}$ St. Petersburg State Polytechnical University, Politekhnicheskaya ul., 29, 195251, Saint Petersburg, Russia
}

\begin{abstract}
The article is devoted to the development of religious buildings of Neogothic style and their stylistic features in the second half of the XVIII century. During the preromantic period the hobby for a Neogothic style in Russia has been connected with idealized idea of customers about the Middle Ages. The gothic style attracted them with exotic shapes. The desire of customers to create illusion of travel to the past over the different countries, typical for a sentimentalism era. was one of the reasons for the emergence of neogothic constructions in the Russian Empire.
\end{abstract}

\section{Introduction}

In the first period of Neogothic style in the Russian Empire on the territory of its capital - St. Petersburg was not built a single church in the Neogothic forms, but those can be seen in the vicinity of the city. It should also be noted that the religious buildings of St. Petersburg in its appearance virtually no features characteristic of Old Russian architecture, differing from that of Moscow.

\section{The Neogothic orthodox churches and chapels built near St. Petersburg in the 2nd half of the XVIII century}

The first of them is the church of St John the Baptist (Figure 1) on Kamenniy Island - Orthodox church built near the city border, (now it is the centre of St. Petersburg) in the style of the early Russian Gothic Revival in the $1776-1778$ by architect Y.M. Felten. It has a cross-shaped plan and its architectural image is similar to the Catholic churches of the Middle Ages, without any details typical to the baroque or Russian Style in its appearance. The original church was built for the hospital of the Baltic Fleet. But then it was transferred to the Order of Malta, after Emperor Paul I became its head. In 1799 Knights of Malta Cemetery was arranged near the church. In this church Cavaliers took the oath. The red brick walls of the church are bare without plaster coating. Window openings have lancet shape and they are decorated with carved white stone details. Dome of the church, built on a high drum with lancet windows, has a conical shape. Above the entrance is single-tiered bell tower, terminated by four-sided tent, supported by four square pillars. The church interior is enclosed with serried lancet Gothic walls. Initially tents, crowning the church and the bell tower, had a concave

${ }^{a}$ Corresponding author : dartigor@mail.ru 
shape, which gave them an even greater resemblance to the churches of the Middle Ages [217 S. 323]. Near the church of St. John the Baptist the building of the Ushakovsky bridge watch was built. Now it is the chapel of the icon "Vsetsaritsa". The building of red brick is a round in plan is situated on the banks of the Big Nevka. Its walls are cut with Gothic lancet windows, stylistically similar to the Church of St. John the Baptist. The upper part of the building walls is crowned with a decorative frieze and above it - the architrave decorated with the chain-like sequence of interconnected undulating arcs. Building dome has the shape of a nearly flat roof, the center of which is decorated with brick drum, topped by a cupola of onion shape with a cross. This building is an example of centric composition which is typical characteristic of classicism.
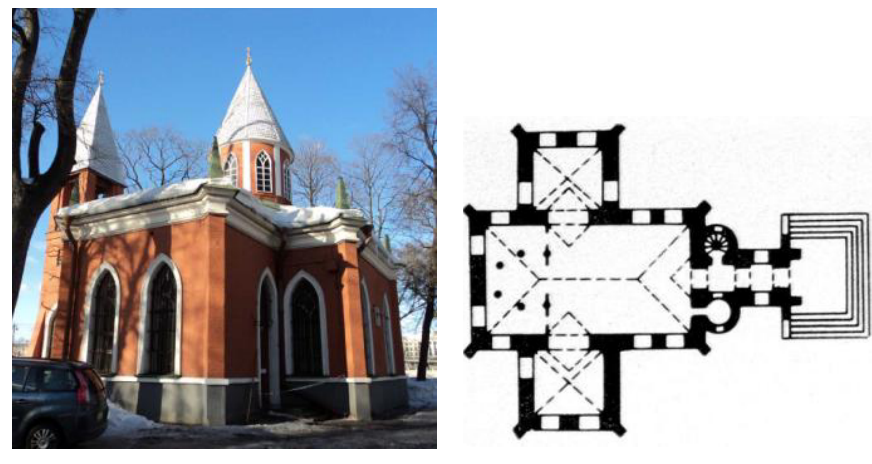

Figure 1. The Church of the Nativity of John the Baptist on Kamenniy Island. St. Petersburg. 1776-78. Y.M. Felten. View from the south-east. Photo by the author, 2011. Plan.

A genuine masterpiece of religious architecture, erected near St. Petersburg, is the Cesma Church (1777-1780) designed by Y.M. Felten. This church got its name in the honor of the victory over Turkey. In the plan it has the shape of quatrefoil as an example of the centric composition, with a strong Baroque influence. The volume of the temple is completed with five domes, each of the domes is topped with a slender spire. Four domes, each of which is surrounded by four pinnacles, placed on the cardinal directions and have throughout openings, and therefore not connected with the interior space of the church. At the same time the central dome has a drum with four big windows, which gives an extra light to the interior. High arched windows, a large number of pinnacles, the vertical division of the facades - all this gives the Chesma church special vertical aspiration and delicacy, close to authentic Gothic buildings. Its interior space filled with light is also close to the medieval concept of the Divine light pouring through the windows, which in the XII century the abbot Suger wrote about. This special role of light, which had a primary importance to the medieval cathedral, is partly typical for Chesma Church. Near the church had previously been two gates and a wooden pavilion, also built in the Neogothic forms, but not extant. The pavilion burned down in 1908, and the gates were dismantled during the restructuring of the Chesma palace in the XIX century. Chesma ensemble can be called the largest and most expressive buildings that were built near St. Petersburg in the early period of Neogothic style in Russia.

\section{Neogothic orthodox churches of the preromantic period in the Russian province}

Further we will pass to the churches built in the Russian province. They show, in general, the same tendency, as temples of Moscow - a mixture both with Russian Old Russian style, and with classicism, and in some cases with baroque. Very often churches were a part of country manors or estates. As a rule, it is explained by following to the general trend: the exotic imitating of antiquity constructions going from the Imperial Court, and supported by the nobility. In the province copies of the Chesma church built by Felten near St. Petersburg were created. Some customers, in particular Batashev, belonged to Masonic lodges that was also affected by a choice of stylistics for the churches 
built on the territories of their estates. It is also necessary to note that both in Moscow, and in country towns of Russia construction of cult buildings in forms typical to second half of XVIII century proceeds and in the XIX century. Thus, early Russian Neogothic style on time of distribution coincided with application of forms of already mature Neogothic style, and almost for 70 years as forms of the all-European Neogothic style in the capital of the empire start being applied about 1800.

One of early churches in the Neogothic style constructed in the Russian province, having in the space-planning solution the features of baroque is the church of the Sign (in Veshalovka of the Lipetsk region). It was built in Tatishchev's manor in 1768-1784, allegedly, on Bazhenov's project. It is onestorey church, which main volume is square in the plan. From the East it is adjoined by a rectangular apse, and from the West the rectangular ante church connected by a refectory to a belltower. A fourlevel belltower with the quadrangle basis and three cylindrical circles of almost identical diameter is topped with a high stone spire. The ante church and an apse are finished by eight pitched roofs. The main volume of church is closed by the close vault which is cut through by lukarn windows and topped with a high spire on the drum surrounded with four pinnacles. Corners of the main volume are strengthened by square towers with sharp stone spires. This church, in my opinion, is advanced version of Archangel Michael Church with richer decoration. The planning structure and the volume decision of church in Veshalovka are typical for the Baroque style.

We will in more detail consider manor copies of Chesma church. The earliest of them is the St. Nicholas Church constructed in the village Posadnikovo of the Novo-Rzhev district in the Pskov province. It was built in the estate of the favourite of Catherine II A. D. Lanskoy in 1782-1784. Some excerpts from earlier documents are given in the artcle about this church published in the Zodchy magazine in 1892. In particular from the church inventory of 1831 where it is told: "The church for the sake of St. Nikolay, stone, Gothic art, semi-circular, is constructed in 1784 for Alexander Dmitriyevich Lanskoy. It is covered with white iron, painted outside and inside by lime, figures above, five-domed. There are 24 quadrangular columns with wooden spires on them, between domes on encircling wall, covered by white iron, on corners finished with white iron apples; crosses with stars above domes, under the crosses are copper domes gilded in pure gold".

The church in Posadnikovo was under construction right after Chesma therefore there is a high probability that works were performed under supervision of Felten, who at the same time was working on reorganization of A. D. Lanskoy house in St. Petersburg. Also a few early mentionings about this monument remained, one of them is in the church inventory of 1831, others are brought together in the case of an estimated demolishion of St. Nicholas Church, stored in archive of the Imperial archaeological commission.

The second one for time of construction is the church of the Transfiguration in the village Krasnoe, constructed in Poltoratsky's manor in 1790. There is an opinion that for construction of this church Poltoratsky ordered someone from architects to copy Felten's drawings to construct the building. As a result a number of changes, in particular, which concerned architectural details in finishings of a portal, sculptures of angels and a form of lancet arches was brought in the project. Arches of church in Krasnoe have more pointed form. In Poltoratsky's archive the drawing different in details from Chesma church, but thus more corresponding to church in Krasnoe remained.

In the same years churches with planning decision, typical for classicism are built. Bright confirmation to that is Church of the Transfiguration in the village the Velikaya Topal (Figure 3) (Bryansk region) built in 1780 in the estate of the count P. A. Rumyantsev-Zadunaysky to replace more ancient wooden temple. 


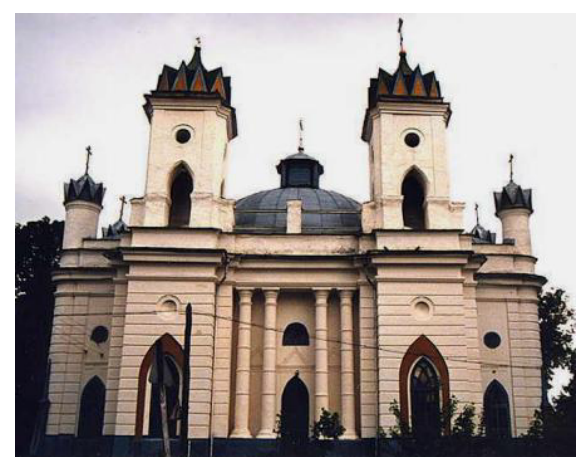

Figure 2. The Church of the Transfiguration. Velikaya Topal. 1780 North façade.

The main volume of the church is a rotunda with two tiers of windows, covered by a cupola, complete with a small octagonal drum and smaller dome. Rotunda is surrounded by four square towers, the northern pair of towers, topped with tents surrounded by gable crowns, significantly higher than the south pair completed with simple tetrahedral tents slightly concave in shape. The appearance of the church is clearly visible mixture of Neogothic and classic features. In general facade detailing is typical for classical buildings, there are also Neogothic pointed arches of door and window openings, as well as the spires and gable crown. Church of the Assumption, built in the S.S. Apraksin's village Peremilovo, perhaps designed by Francesco Kamporezi in 1792. If church in the village of Velikaya Topal (Figure 3) mentioned above, shows the use of the classic composition, but with some original interpretation, in the case of the Ascension church in the village Peremilovo in the plan decision and facades there is absolute adherence to the classical canons, disturbed only by using gothic decorations. The volume of the temple is a massive quadrangle, surmounted by a hemispherical dome on a low drum, with the completion of a small drum with a decorative cupola. Similar composition with Neogothic details and tripartite division of the facade demonstrates the baptismal church of the Kazan Church in Puchkovo village, built in 1802 by Khitrovo landowners, as well as the church of St. Nicholas in Rzhavki (in Moscow) started in 1805 and completed in the 1818-1820, when Andrei Nikolaevich Dolgorukov owned the estate. The church in Rzhavki was supplemented by a freestanding three-tiered bell tower with rectangular extensions. All of these three monuments demonstrate the classic earthiness and a complete lack of vertical aspiration typical for the Gothic style.

Then let us take a closer look at a few of the provincial Neogothic churches with a marked influence of the Baroque style, and above all, Novo-Nikolsky cathedral in Mozhaisk (Fig. 3), built on the site of the Nicholas Gate in the Kremlin of Mozhaisk in 1779-1814. It is quite exceptional work of early Russian Gothic Revival with strong baroque features. The cathedral was completed by the dome rotunda (lost during the Second World War), surrounded by four towers with a small bulbous dome. These four towers remind belvedere of Tsaritsyno Palace and the tower of the church in the village Bykovo. The four-tiered high belltower, adjacent to the cathedral from the west topped by a sharp spire, surrounded by pinnacles, is full of classical and baroque elements. In silhouette, it is close to the early works of M.F. Kazakov.
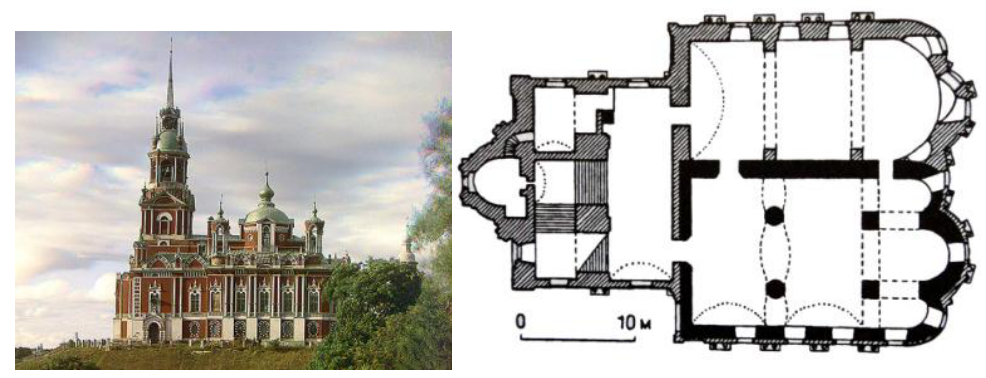

Figure 3. New Nicholas Cathedral. Mozhaysk. 1779-1814. The architect M.F. Kazakov. Photo XX century. Plan. 
Church of Our Lady of Vladimir in Bykovo (Figure 4) was designed by Vasily Bazhenov in 1789. The church is different quite significantly from the original project (Figure 6), in which there was no grand staircase leading to the main entrance. The church building consists of two churches - the top in honor of the Vladimir Icon of the Mother of God and the bottom - of Christ. The bulk of the temple oval in plan, is delivered on high basement; from the west a rectangular refectory with two belltowers at the corners was attached to it. The bulk of the light rotunda is completed with high spire at the top. It is surrounded by a crown composed of the same spires. On each side of the oval in the main volume of the church are tall lancet windows, between which are placed decorative porches with columns flanking the side entrances. This temple is rare for the period of the early Russian Neogothic example of composition with two-towered western facade, typical for the Western European, mainly French, Middle Ages. Moreover, the temple was built of stone, which was also relatively rare.
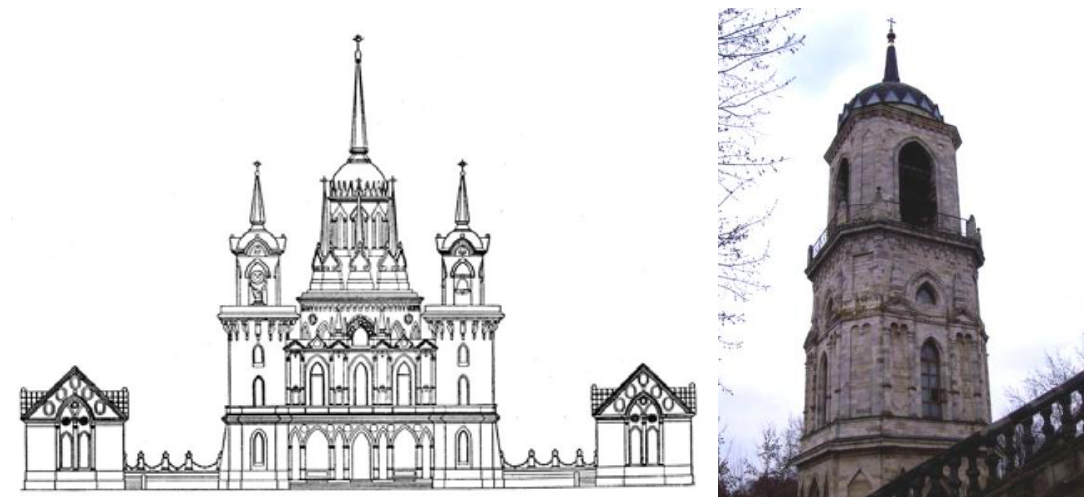

Figure 4. The Church of Our Lady of Vladimir. Village Bykovo. Project V.I. Bazhenov 1782. Bell tower of the XIX century.
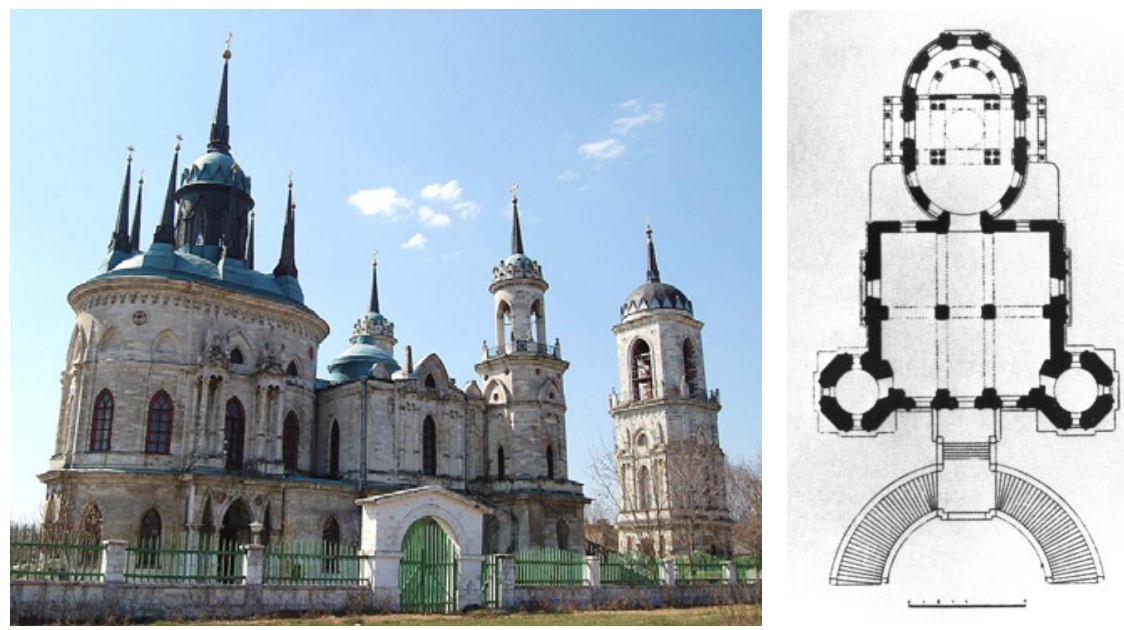

Figure 5. Our Lady of Vladimir Church. Village Bykovo. Architect V. I. Bazhenov. 1789. View from the northeast. Plan. V. I. Bazhenov's project of 1782.

Holy Trinity Church in Batashev's manor, Gus-Zhelezny (Figure 10) of 1802-1868. This twostoried church, also as well as church in Bykovo, is built of a white stone. On the planning structure it is crosswise, however this cross form is created by three apses surrounding its east part. From the West the church is added with a refectory and a belltower with a rectangular ante church. Construction works on this temple were actively conducted till 1825 , by this time a refectory with a belltower were 
brought to eaves level, and the main building of church - to the level of the main dome. Further works were resumed in 1847 , and came to the end only by 1868 . This church as some researchers consider, is the largest rural temple in the territory of Russia. In the shape the church combines features of baroque, classicism and an early Russian Neogothic style. Who from architects possesses the project of church still isn't established: on the one version the author of the project is I. S. Gagin, on another V. I. Bazhenov, the third names M. F. Kazakov as the author. In my opinion, the project was executed by I. S. Gagin. My point of view is based on that Bazhenov and Kazakov's constructions doesn't possess such laconicism and at the same time monumentalism and ponderousness. Despite considerable height this church makes impression of massiveness and monumentalism that is partly connected with laconicism in use of the front detailing.
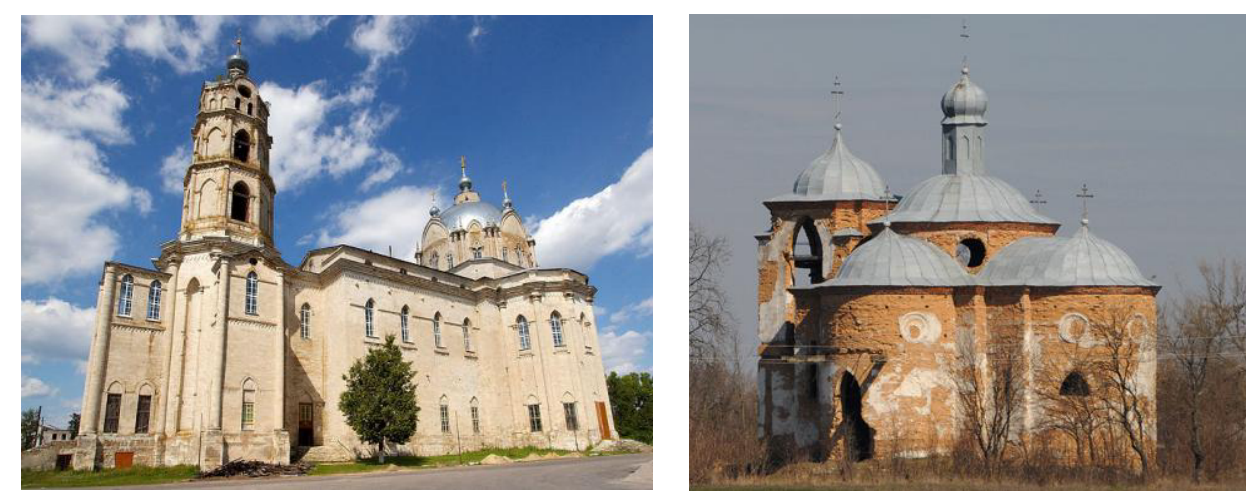

Figure 6. a) Holy Trinity Church. Batashev's manor. City of Gus-Zhelezny (1802-1868), b) Church of Saints Peter and Paul. Mosviyka. Estate Volkhovsky. Ukraine. 1808. View from the southeast

Influence of early Russian Neogothic style can be observed as well in Ukraine that is confirmed by existence of Church of Saints Peter and Paul in Mosviyka (Figure 7), (The Cherkassk Region, earlier Piryatinsky district of the Poltava province, Ukraine) built in 1808 as a part of complex of constructions of Volkhovsky's estate. It shows a mixture of Gothic, classical and baroque elements. This centric building with the square two-storey belltower attached from the West and three semicircular apses located on cardinal directions. Lancet arches in its shape are combined with domes, characteristic for a baroque era, and also with constructive system of classicism. The central part of church is covered by a hemispherical dome on pendentives, western - the semi-circular vault. Most likely, that initially the temple was Catholic, and from the middle of the XIX century became the Orthodox Christian. This church has very considerable sizes: its length is $27 \mathrm{~m}$, width is $19,4 \mathrm{~m}$.

In some cases it is possible to observe examples of construction of stand alone belltowers with application of Neogothic shapes. Its construction is the same as earlier built orthodox churches. The phenomenon of this which began in the XVIII century will proceed during the second stage of development of Neogothic style in Russia in the XIX century. One of early examples of such constructions is the belltower in Pyotr Dmitriyevich Eropkin's (Fig. 8) estate (Grabtsevo, Kaluga region) 1791. This belltower is separate, with a rich set of various Gothic architectural details. In many aspects reminds a belltower of the Zachatyevsky monastery, however documents on Kazakov's authorship concerning this complex didn't remain.

One more rather expressive sample of a belltower, constructed near ancient cathedral is the belltower of Assumption Cathedral in Vladimir (Fig. 9) built on the project of the architect A. N. Vershinsky in $1810.56 \mathrm{~m}$ in height it has four levels, the first three of which are quadrangle, and cylindrical at the top. Lower, more massive, quadrangle level on corners is finished by four round turrets with gear parapets. Corners of the second level are decorated with pinnacles. The belltower is topped with a gilded dome with a high graceful spire. In its shape Neogothic, classical and Old Russian motives are clearly visible.

In the Russian province in the 2nd half of the XVIII century as well as in Moscow, there was a 
tendency on unusual Gothic constructions. Rebuilding of more ancient temples in Neogothic style was sometimes carried out. This phenomenon is demonstrated by the church of the Assumption of the Blessed Virgin in the village Bernovo (Fig. 8) built in 1687-1699 in Baroque style, which later received the three level Neogothic belltower.

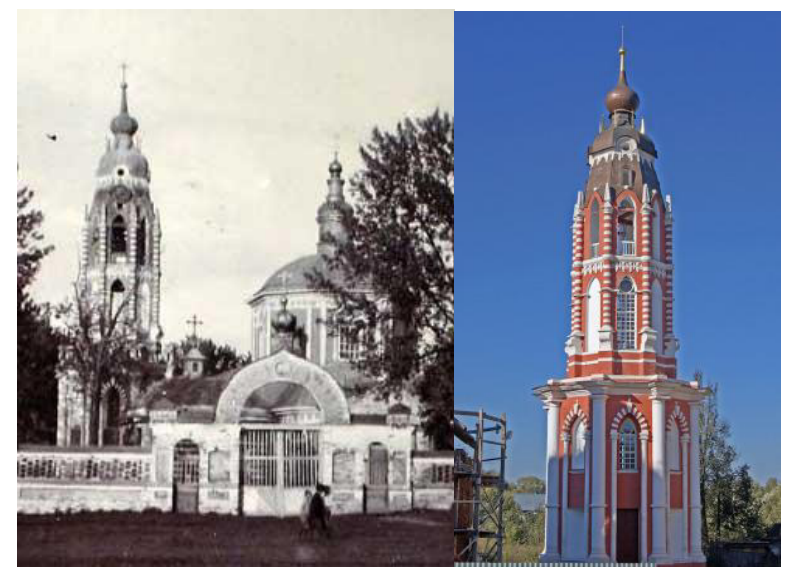

Figure 7. A belltower in P. D. Eropkin's estate. Grabtsevo. 1791. Architect M. F. Kazakov. Photo of 1905. General view.

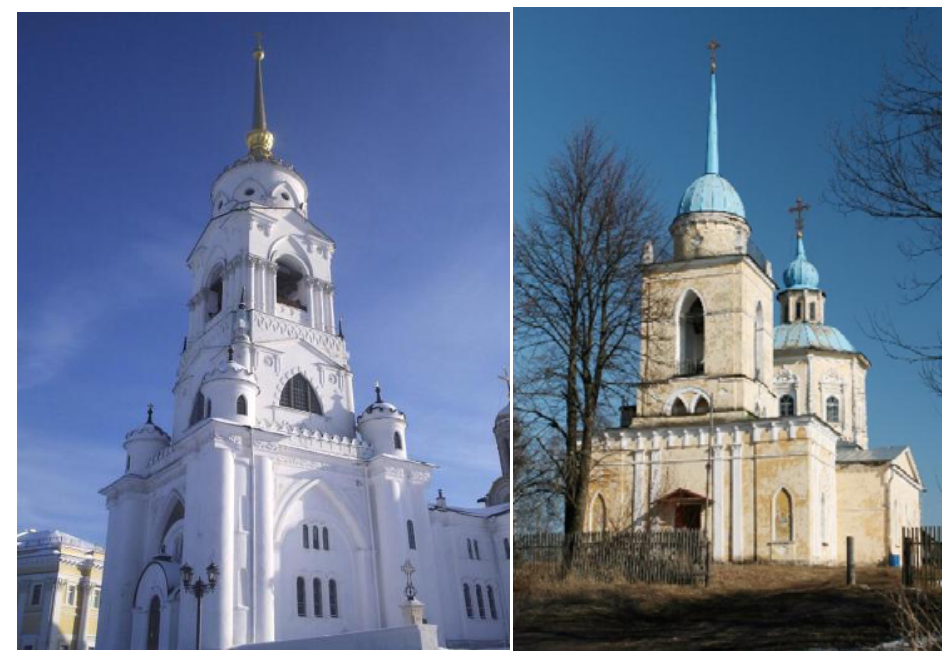

Figure 8. a) Assumption Cathedral belltower. City of Vladimir. Architect A. N. Vershinsky (1810), b) Church of the Assumption of the Blessed Virgin. Village Bernovo. 1687-1699

Special type of constructions in style of an early Neogothic are monastic walls with towers. In their appearance we see mixture of the gothic and classic shapes. One of the most expressive monuments of this kind are the towers of the walls of Spaso-Yakovlensky Dmitriyev (Figure 9) monastery in the Rostov region constructed in the 2nd half of the XVIII century. Towers of the monastery have two levels, and second level is octahedral, completed with different tents or domes with spires. The towers with domes located in the central parts of walls are decorated with pinnacles, which are on the first level quadrangle, and on the second level - octagonal. The first level of towers have features of classicism: semi-circular arches, simple round windows, and one of towers has even a Doric portico. 


\section{MATEC Web of Conferences}
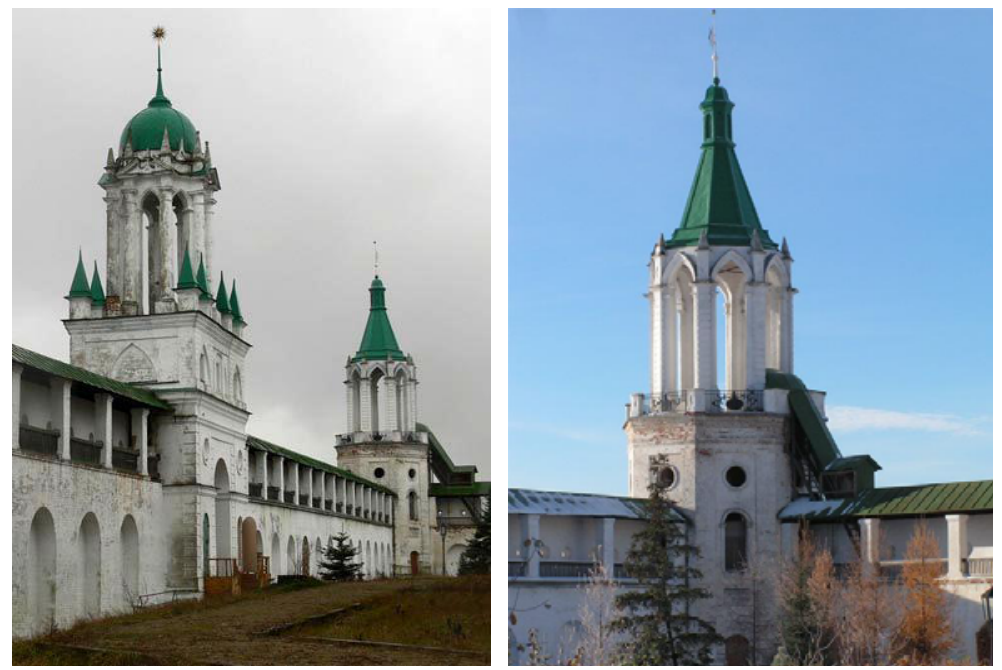

Figure 9. Towers of a wall of Spaso-Yakovlensky Dmitriyev of the monastery. Rostov region. 2nd half XVIII century.

Walls of the Staro-Golutvin's monastery (Fig. 10). Kolomna. 90th of the XVIII century. Neogothic towers of a wall made of a red brick have a Gothic and classical details of a white stone. Their first level has a cylindrical shape. The towers are different: some of them low, almost without windows, topped with domes, some - high with the stone conic truncated tents decorated with a white stone details. Over these tents is the top cylindrical level which is richly decorated, topped with conic spires. However as all Neogothic towers built by M. F. Kazakov it have rather rich filigree detailing like towers of the Petrovsky palace.
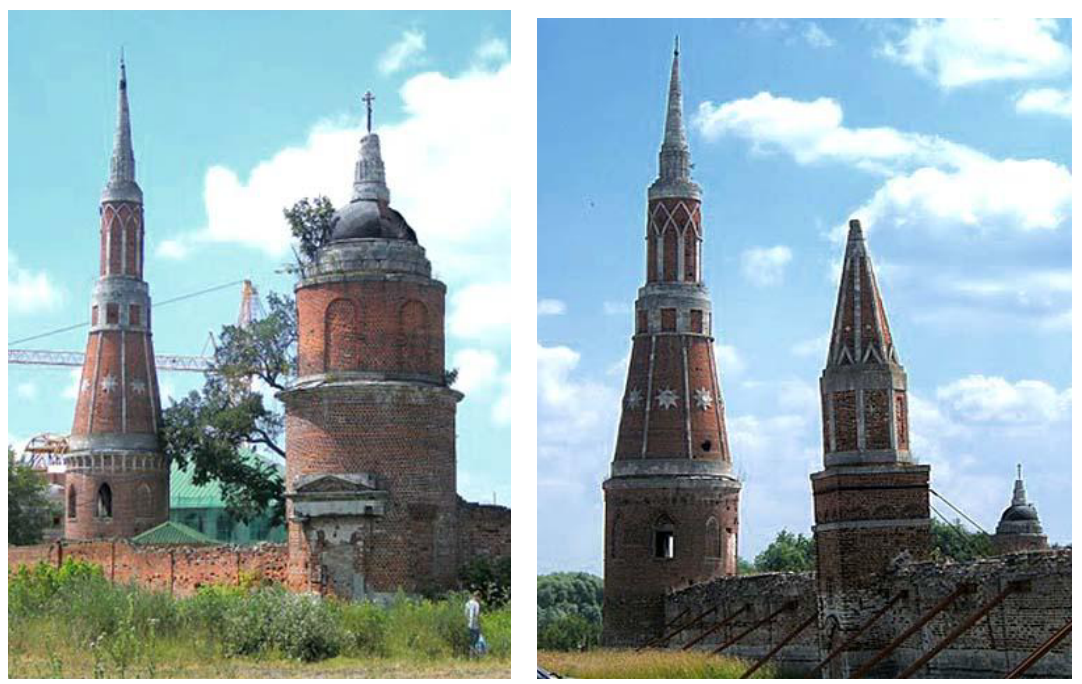

Figure 10. Walls of the Staro-Golutvin's monastery. Kolomna. 1790th. Architect M. F. Kazakov.

\section{Conclusion}

In the Russian Empire within the Age of Enlightenment worldview to the middle of the XVIII century have developed such common cultural situation which has allowed a Gothic subject, inherently alien to the Russian art, to be shown brightly also in architectural works. It has been directly connected with the Western European influence which has amplified due to establishment of 
more close cross-cultural ties. Gothic images, getting on the Russian soil, as a rule, are enriched and supplemented with various elements, intertwine with national Russian, classical, baroque and mannerist motives.

\section{References}

1. Architect Yury Felten. To the 250 anniversary since birth. Exhibition catalog: Art (1982) $55 \mathrm{p}$.

2. M. G. Baranova, "Gothic style" in the Russian architecture of the second half of XVIII (on the example of monuments of St. Petersburg and its suburbs): RGPU of Herzen (2005) $242 \mathrm{p}$.

4. N. A. Evsina, Russian architecture during Catherine II's era (1994) Moskva: Science, 223 p.

5. S. I. Razgonov, Vasily Ivanovich Bazhenov (1985) Moskva: Art, 168 p.

6. I. Yamshanov, V. Goryunov, V. Murgul, Procedia Engineering, 117, 675-684 (2015)

7. I. Yamshanov, V. Murgul, N. Vatin, Applied Mechanics \& Materials, 740, 1192 (2014)

8. I. Yamshanov, V. Goryunov, V. Murgul, Procedia Engineering, 117, 663-674 (2015)

9. I. Yamshanov, V. Goryunov, V. Murgul, N. Vatin. Advanced Materials Research, 1065-1069, 2669-2673 (2015) 